\title{
Mu and kappa opioid receptors of the periaqueductal gray stimulate and inhibit thermogenesis, respectively, during psychological stress in rats
}

\author{
Caroline Cristina-Silva $^{1,2} \cdot$ Victor Martins $^{1,2} \cdot$ Luciane H. Gargaglioni $^{1,2}$ • \\ Kênia C. Bícego ${ }^{1,2,3}$
}

Received: 22 December 2016 / Revised: 20 February 2017 / Accepted: 6 March 2017 /Published online: 4 April 2017

(C) Springer-Verlag Berlin Heidelberg 2017

\begin{abstract}
The periaqueductal gray matter $(\mathrm{PAG})$ is rich in mu and kappa opioid receptors, and this system is involved in thermoregulation, analgesia, and defensive behaviors. No study approached the involvement of the PAG opioids in body temperature $(\mathrm{Tb})$ regulation during psychological stress such as restraint. Because activation of mu and kappa receptors increases and reduces $\mathrm{Tb}$, respectively, we tested the hypothesis that they exert excitatory and inhibitory modulation, respectively, of the restraint-induced fever in rats. To this end, $\mathrm{Tb}$, heat loss index (HLI, inference for peripheral vasoconstriction/vasodilation), and oxygen consumption (inference for thermogenesis) were monitored in unanesthetized rats, restrained or unrestrained, before and after intra-PAG microinjection of the selective mu opioid receptor antagonist (D-PheCys-Tyr-D-Trp-Arg-Thr-Pen-Thr-NH $\mathrm{NH}_{2}$ cyclic, CTAP; 1 and $10 \mu \mathrm{g} / 100 \mathrm{~nL}$ ) or the selective kappa opioid receptor antagonist (nor-binaltorphimine dihydrochloride, nor-BNI; 1 and $4 \mu \mathrm{g} / 100 \mathrm{~nL}$ ) or saline (100 nL). CTAP and nor-BNI did not change the Tb or HLI of euthermic animals. During restraint, $\mathrm{Tb}$ increased $\left(1.0 \pm 0.1^{\circ} \mathrm{C}\right)$ in all groups; however, this effect was lower in those animals treated with CTAP and higher in animals treated with nor-BNI. The HLI decreased during
\end{abstract}

Kênia C. Bícego

keniacb@fcav.unesp.br; keniacb@yahoo.com.br

1 Department of Animal Morphology and Physiology, College of Agricultural and Veterinarian Sciences, São Paulo State University, Jaboticabal, SP 14884-900, Brazil

2 National Institute of Science and Technology in Comparative Physiology (INCT-Fisiologia Comparada), Jaboticabal, SP, Brazil

3 Departamento de Morfologia e Fisiologia Animal, Faculdade de Ciências Agrárias e Veterinárias, Universidade Estadual Paulista Júlio de Mesquita Filho, Via de acesso Paulo Donato Castellane s/n, Jaboticabal, SP 14884-900, Brazil restraint and increased after animals were released, but this response was not affected by any treatment. Restraint stress increased oxygen consumption ( $35.9 \pm 3.9 \%$ elevation), but this response was diminished by CTAP and overstimulated by nor-BNI. Confirming our hypothesis, the results indicate that the mu and kappa opioid receptors in the PAG of rats play a pyrogenic and antipyretic role, respectively, during fever induced by restraint by affecting the thermogenic but not the heat conservation effector.

Keywords Body temperature $\cdot$ Heat loss index $\cdot$ Oxygen consumption $\cdot$ Opioid receptors $\cdot$ Nor-BNI $\cdot$ CTAP

\section{Introduction}

Body temperature $(\mathrm{Tb})$ affects the body's biochemistry and physiology in such a way that its maintenance becomes especially important. There are certain situations, however, in which changes in $\mathrm{Tb}$ are induced by endogenous mechanisms, such as during fever, which is known to be a regulated increase in $\mathrm{Tb}$ [45]. In this case, the brain plays an important role in converting the pyrogenic peripheral signals into appropriate adjustments on thermal effector activity (increasing heat conservation and/or production) [50].

Besides inflammatory agents, some stressor stimuli, including manipulation, open-field exposure, new environment exploration, or restraint, can also induce a rise in $\mathrm{Tb}$ in several mammalian species [30, 48, 67, 68, 82]. Handling stress and the introduction of a new individual into the same cage have also been demonstrated to induce an increase in preferred $\mathrm{Tb}$ in lizards, animals that thermoregulate primarily by behavioral mechanisms [21, 44]. The higher Tb may increase physical and neural performance [16], which can be beneficial for survival during psychogenic stressful situations. In addition, 
some data in mammals have indicated that the increase in $\mathrm{Tb}$ induced by stress shows similar mechanisms to fever induced by endotoxins $[27,51,57,63,68,75,78,80]$. In psychological stress, the brain seems to play a role in both the detection of the stress signal and the activation of appropriate thermoregulatory responses.

Endogenous opioids are possible mediators of the thermal response to psychogenic stress because they are a class of molecules with numerous effects, many of which are associated with stress responses [5] and thermoregulation [4, 9, 17, $34,35,77,91]$. Three types of opioid receptors, mu, kappa, and delta $[46,52,69]$, were described to be expressed in many brain regions $[24,47,62,74]$. The mu and kappa receptors seem to have opposite effects on $\mathrm{Tb}$, where mu is involved in Tb increases [8, 18, 38, 39, 81, 92], including the development of endotoxin-induced fever [13, 14, 32], while kappa is related to $\mathrm{Tb}$ decreases $[22,81,92]$ including the hypoxia-induced anapyrexia, an opposite response to fever [77]. The role of the delta opioid receptors in thermoregulation can involve different effects depending on the agonist or antagonist selectivity $[19,24,38,71,74,77,81]$.

One of the brain regions rich in opioid receptors is the periaqueductal gray matter (PAG) $[36,54]$ which is involved in autonomic regulation of defensive behaviors [28], nociception, anxiety, analgesia, cardiorespiratory control, and thermoregulation $[11,28,59,60,66,87,98]$. Intriguingly, most studies about the role of the PAG in behavioral responses to stress do not consider the possible changes induced in $\mathrm{Tb}$. This region contains $\beta$-endorphin [31] and expresses a significant density of mu and kappa opioid receptors [36, 54]. Naloxone inhibits the hyperthermia induced by $\beta$-endorphin and DAGO (a selective agonist for mu receptors) in the PAG, which suggests the action of mu receptors of the PAG to increase $\mathrm{Tb}$ [90]. Besides these facts, PAG is involved in the activation of heat loss (cutaneous vasodilation of the rat tail) $[96,97]$ and heat production (non-shivering thermogenesis in the brown adipose tissue, BAT) [23] mechanisms. Moreover, there is evidence of functional connections between PAG and hypothalamic regions involved in warmthdefense responses, the median preoptic nucleus (MnPO), and in thermogenesis, the dorsomedial hypothalamus (DMH) [94]. All those data together suggest an important role for the opioid system of PAG in the efferent pathways of autonomic thermoregulation and make this system a possible network for the development of restraint-induced fever. In fact, restraint stress is widely used as a model of unconditioned and unavoidable stress-elicited neuroendocrine, cardiovascular, and thermal responses [27, 75, 80, 84, 85].

Based on the considerations above, we hypothesized that opioid receptors, mu and kappa, in the PAG are involved in the induction and inhibition, respectively, of restraint-induced fever in rats. To this end, we investigated the effect of intraPAG microinjection of selective antagonists for mu (D-Phe-
Cys-Tyr-D-Trp-Arg-Thr-Pen-Thr-NH ${ }_{2}$ cyclic, CTAP) and kappa (nor-binaltorphimine dihydrochloride, nor-BNI) opioid receptors on $\mathrm{Tb}$, as well as on heat production (oxygen consumption) and heat conservation (heat loss index) effector mechanisms in rats subjected to restraint stress.

\section{Materials and methods}

\section{Animals}

Experiments were performed on adult male Wistar rats weighing $250-280 \mathrm{~g}$. Animals had free access to water and food and were housed in a temperature-controlled chamber at $25 \pm 1{ }^{\circ} \mathrm{C}$ (model: ALE 9902001; Alesco, Monte Mor, SP, Brazil) with a $12 \mathrm{~h}: 12 \mathrm{~h} \mathrm{light/dark} \mathrm{cycle} \mathrm{(lights} \mathrm{on} \mathrm{at} 0630$ hours). All the experimental protocols were conducted with the approval of the local animal care committee of the College of Agricultural and Veterinarian Sciences, São Paulo State University (CEUA; protocol no. 007094/13).

\section{Drugs}

CTAP (a selective mu opioid receptor antagonist; 1 and $10 \mu \mathrm{g}$ / $100 \mathrm{~nL} /$ animal) and nor-BNI (a selective kappa opioid receptor antagonist; 1 and $4 \mu \mathrm{g} / 100 \mathrm{~nL} /$ animal) were purchased from Sigma-Aldrich (São Paulo, Brazil). Drugs were dissolved in pyrogen-free sterile saline. Doses were chosen on the basis of preliminary experiments and previous reports $[13,74,77]$.

\section{Surgery and microinjection}

Animals were anesthetized with ketamine $(100 \mathrm{mg} / \mathrm{kg}$, intraperitoneal) and xylazine (10 mg/kg, intraperitoneal), fixed in a stereotaxic frame (David Kopf, model 900, Tujunga, CA, USA), and implanted with a stainless steel guide cannula ( $0.6 \mathrm{~mm}$ o.d. and $12 \mathrm{~mm}$ in length) $2 \mathrm{~mm}$ above the dorsal periaqueductal gray region (dorsomedial and dorsolateral PAG; tower angle $22^{\circ}$ to the left; coordinates relative to lambda/antero-posterior $+1.1 \mathrm{~mm}$; latero-lateral $+1.9 \mathrm{~mm}$; dorso-ventral $-3.2 \mathrm{~mm}$ from the skull surface; incisor bar $-2.5 \mathrm{~mm}$ ). These coordinates were adapted from Paxinos and Watson atlas [70]. The cannula was attached to the bone with stainless steel screws and acrylic cement. A tight-fitting stylet was kept inside the guide cannula to prevent occlusion. Additionally, animals of all groups were submitted to paramedian laparotomy in order to insert a data logger (SubCue Dataloggers, Calgary, Canada) into the abdomen for body temperature measurements. After surgery, animals were treated with antibiotic (enrofloxacin, $10 \mathrm{mg} / \mathrm{kg}$, intramuscular) and non-steroid anti-inflammatory (flunixin meglumine, $2.5 \mathrm{mg} / \mathrm{kg}$, subcutaneous) agents. Experiments were initiated 1 week after surgeries. 
The microinjections were performed in unrestrained animals, a procedure that is routinely employed in our laboratory, using a regular Hamilton syringe $(5 \mu \mathrm{L})$ and a dental injection needle (Mizzy, $200 \mu \mathrm{m}$ o.d.) attached by a PE-10 tube. The syringe and the tube were filled with sterile water, with an air bubble separating it from the drug, and the injected volume was evaluated visually by monitoring the movement of the water-air-drug interface. The injection needle was $2 \mathrm{~mm}$ longer than the guide cannula so that the PAG can be reached by the needle only at the time of injection. A volume of $100 \mathrm{~nL}$ of vehicle or antagonist solution was injected over a period of $30 \mathrm{~s}$, and $30 \mathrm{~s}$ more was allowed to elapse before the injection needle was removed from the guide cannula to avoid reflux. All $100 \mathrm{~nL}$ injection volumes were precisely administered using a microinjector machine (model 310, Stoelting Co., IL, USA).

\section{Histology}

Upon completion of the experiments, animals were deeply anesthetized with ketamine $(100 \mathrm{mg} / \mathrm{kg}$, intraperitoneal $)$ and xylazine (10 mg/kg, intraperitoneal) and injected with $100 \mathrm{~nL}$ of $2 \%$ Evan's Blue solution through the guide cannula. Rats were then perfused through the left cardiac ventricle with saline followed by $10 \%$ formalin. The brain was removed and stored in $10 \%$ formalin for at least 2 days, embedded in paraffin, sectioned on a microtome (15- $\mu \mathrm{m}$-thick coronal sections), and stained by the Nissl method for light microscopy determination of the region reached by the microinjection. Microinjections were considered intra-PAG when given directly into the PAG, and peri-PAG when located in nuclei surrounding the PAG.

\section{Determination of body temperature}

SubCue Dataloggers (Calgary, AT, Canada) were connected to a computer via optic connection and programmed to acquire data every 5 min using the software SubCue Temperature Datalogger. At the end of the experiments, data loggers were connected again to the computer and temperature values were corrected according to the specifications of the manufacturer's manual.

\section{Determination of the heat loss index}

The skin temperature (Ts) of the tail was measured by means of infrared images using a camera sensitive to such radiation (FLIR SC660, Switzerland). This technique has been commonly used to infer the peripheral blood flow (heat loss/conservation) in rats because the tail is considered a thermal window in these animals $[7,73,83,89]$. We determined the average of three values of skin temperature for the middle third of the tail length, where temperatures have reduced interference from (1) the body, because the temperature of the base of the tail is higher (influence of $\mathrm{Tb}$ ), and
(2) the environment, because the temperature at the tip of tail is closer to that of the environment [73]. The $\mathrm{Tb}$ and $\mathrm{Ts}$ were used to infer the heat loss index (HLI) of the animal, which ranges from 0 to 1 ( 0 indicates maximum vasoconstriction and 1 is maximum vasodilation), and was calculated according to the formula: $\mathrm{HLI}=(\mathrm{Ts}-\mathrm{Ta}) /(\mathrm{Tb}-\mathrm{Ta})$, where $\mathrm{Ta}$ is the ambient temperature [73].

\section{Determination of oxygen consumption}

Metabolic rate was inferred through oxygen consumption measured in an open respirometry system. A continuous flow of air was maintained in the experimental chamber where the inflow and outflow $\mathrm{O}_{2}$ concentrations were monitored by an $\mathrm{O}_{2}$ analyzer (Sable Systems International, Inc., Las Vegas, NV, USA) connected to a computer to record and store data. The oxygen consumption $\left(\mathrm{V}_{2}\right)$ was determined based on the flow rate and gas concentration differences between the inlet $\left(\mathrm{FiO}_{2}\right)$ and outlet $\left(\mathrm{FeO}_{2}\right)$ of the chamber. Air was pulled into the respirometer at a rate of $1700 \mathrm{~mL} \mathrm{~min}^{-1}$ and passed through an analyzer of water vapor pressure (RH300; Sable Systems, Las Vegas, NV, USA), but only a subsample of this air was pulled through the $\mathrm{O}_{2}$

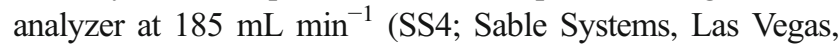
NV, USA). Each $10 \mathrm{~min}$ of recording was composed of $2 \mathrm{~min}$ of baseline, a sample of incurrent air, and 8 min of excurrent air. Baseline was taken to ensure that $\mathrm{O}_{2}$ in the air offered to the animal remained constant throughout the experiment and to provide the estimates of $\mathrm{F}_{\mathrm{i}} \mathrm{O}_{2}$. A gas flow distributor (RM8 Intelligent Multiplexer; Sable Systems) was used to control which gas sample (from respirometer or baseline) entered the analyzers. All data were recorded using a data acquisition system (ExpeData v. 1.4.5; Sable Systems), collecting values every second. The $\mathrm{O}_{2}$ analyzer was calibrated using nitrogen as a zero value and dried air $\left(20.95 \% \mathrm{O}_{2}\right)$ as span. $\mathrm{As}^{\mathrm{CO}_{2}}$ was neither analyzed nor scrubbed, the $\mathrm{VO}_{2}$ was calculated using the following equation [53]: $\mathrm{VO}_{2}=\left[\mathrm{FR}_{\mathrm{e}}\left(\mathrm{F}_{\mathrm{i}} \mathrm{O}_{2}-\mathrm{F}_{\mathrm{e}} \mathrm{O}_{2}\right)\right] /\left[1-\mathrm{F}_{\mathrm{i}} \mathrm{O}_{2}\right.$ $(1-\mathrm{RQ})$ ], where $\mathrm{FR}_{\mathrm{e}}$ is the excurrent flow rate, $\mathrm{F}_{\mathrm{i}} \mathrm{O}_{2}$ is the incurrent fractional concentration of oxygen (baseline), $\mathrm{F}_{\mathrm{e}} \mathrm{O}_{2}$ is the excurrent fractional concentration of oxygen, and RQ is the respiratory quotient (considered 0.85 ). Since the air was not dried during the experiment, $\mathrm{FR}_{\mathrm{e}}$ was corrected according to the following formulas: $\mathrm{FR}_{\mathrm{e}}=\mathrm{FR}_{\mathrm{e}} \times(\mathrm{BP}-\mathrm{WVP}) / \mathrm{BP}$, $\mathrm{F}_{\mathrm{i}} \mathrm{O}_{2}=\mathrm{F}_{\mathrm{i}} \mathrm{O}_{2} \times \mathrm{BP} /(\mathrm{BP}-\mathrm{WVP})$, and $\mathrm{F}_{\mathrm{e}} \mathrm{O}_{2}=\mathrm{F}_{\mathrm{e}} \mathrm{O}_{2} \times \mathrm{BP} /$ (BP - WVP), where BP is the barometric pressure and WVP is the water vapor pressure. Data are shown in standard conditions of temperature, pressure, and dry air (STPD).

\section{Experimental protocol}

The experiments were conducted in unanesthetized animals implanted with a temperature data logger $(\mathrm{Tb}$ each $5 \mathrm{~min}$ ) in the abdominal cavity. Animals were placed in individual cages in the 
experimental room $\left(\mathrm{Ta}=25-27^{\circ} \mathrm{C}\right)$ during the afternoon, and the experiments were performed the next morning. Each animal received an intra-PAG microinjection of CTAP, nor-BNI, or saline (vehicle). Animals were randomly divided into two groups: (a) control rats, which received treatments and stayed in their cages without disturbance during the entire experiment, and (b) restraint stress rats, which were placed inside the restraint tube (60 $\mathrm{mm}$ o.d.) in their cages $50 \mathrm{~min}$ after microinjection (time needed to avoid handling stress before restraint stress), and remained there for $40 \mathrm{~min}$. After the restraint stress, the rats were kept in their cages for a recovery period of $50 \mathrm{~min}$. The time of action of the antagonists is long enough for them to be active for the duration of the experiment $[1,20,29,49]$. During experiments where animals were not subjected to restraint stress, thermal tail images were captured at 30,60, 90, and $120 \mathrm{~min}$, and in experiments where animals were subjected to restraint stress, images were captured at $30,35,45,50,55,60,65,70,75,80$, $90,95,100,105,110$, and $130 \mathrm{~min}$.

Oxygen consumption was determined in a separate group of animals: (a) control group, which received treatment and remained undisturbed in the respirometer $(6.8 \mathrm{~L})$ throughout the experiment, and (b) restraint stress group, which was placed inside the restraint tube after $50 \mathrm{~min}$ of microinjection and remained there for $40 \mathrm{~min}$ and for an additional $50 \mathrm{~min}$ of recovery. The dose of CTAP and nor-BNI $(1 \mu \mathrm{g} / 100 \mathrm{~nL})$ that affected $\mathrm{Tb}$ during restraint in the previous protocol was chosen for the oxygen consumption experiments. Both treatments and conditions were applied in a random fashion.

\section{Statistical analysis}

Data are shown as mean $\pm \mathrm{SEM}$. The initial Tb, $\mathrm{HLI}$, and $\mathrm{VO}_{2}$, i.e., before any microinjection, were compared among all animal groups by one-way ANOVA. The effects of the opioid receptor antagonists, CTAP and nor-BNI, on Tb, HLI, and $\mathrm{VO}_{2}$ were analyzed through the analysis of variance (two-way ANOVA) for repeated measures (factors: treatment and time) followed by Tukey's test. In the experiments in which animals were subjected to restraint, the periods of restraint and post-restraint were analyzed separately for evaluating treatment effects. Significant differences were considered for $p<0.05$.

\section{Results}

Microinjection sites in the dorsal PAG are shown in Fig. 1a, and the representative diagrams of microinjection sites are shown in Fig. 1b. The intra-PAG microinjections were located in the dorsolateral and dorsomedial PAG, sites where mu and kappa opioid receptors are known to be expressed [36]. Because of the reduced number of peri-PAG animals injected with each dose of the antagonists and their similar results to
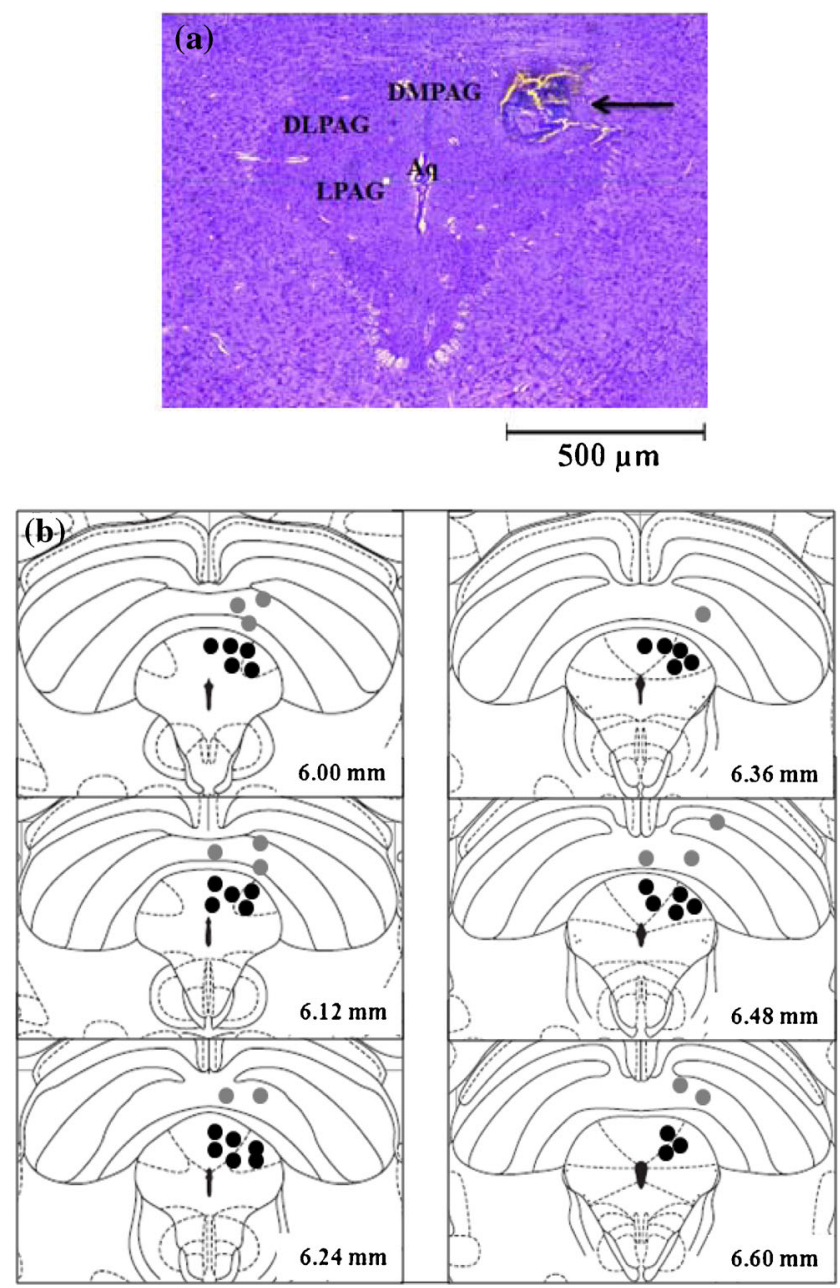

Fig. 1 a Photomicrography of the brain of a representative animal showing the typical microinjection site (arrow) in the dorsolateral periaqueductal gray matter $(D L P A G)$. b Representative diagrams showing microinjection sites intra-PAG (black circles) and outside-PAG (gray circles) at distances (in mm) caudal to the bregma [67]. DMPAG dorsomedial PAG, $L P A G$ lateral PAG, $A q$ aqueduct

saline, the peri-PAG groups in all graphs of $\mathrm{Tb}, \mathrm{HLI}$, and $\mathrm{VO}_{2}$ were composed of a pool of animals that received both doses of the drugs.

Prior to any treatment, $\mathrm{Tb}, \mathrm{HLI}$, and $\mathrm{V}_{2}$ were not different among all the experimental groups $\left(p=0.304, F_{(6,112)}=1.217\right.$ for $\mathrm{Tb} ; p=0.085, F_{(6,112)}=1.928$ for HLI; and $p=0.844$, $F_{(4,61)}=0.348$ for $\left.\mathrm{V}_{2}\right)$. In addition, the pattern of changes in skin temperature of the tail in all groups and treatments (data not shown) was similar to those of HLI.

\section{Effect of intra-PAG microinjection of the selective mu opioid receptor antagonist, CTAP, on the Tb, HLI, and $\dot{\mathrm{V}} \mathrm{O}_{2}$ of restrained and unrestrained rats}

Saline or the two doses of CTAP microinjected into the PAG did not change the $\mathrm{Tb}$ of non-stressed rats (no effect of time: $p=0.240, F_{(3,32)}=1.244$; no effect of treatment: $p=0.868$, 
$F_{(3,32)}=0.239$; Fig. 2a). The same lack of treatment effect was observed in HLI (no effect of time: $p=0.111, F_{(3,32)}=2.057$; no effect of treatment: $p=0.488, F_{(3,32)}=0.830$; Fig. $2 b$ ).

Figure 3 shows the results of microinjection of saline or CTAP in the PAG of rats subjected to restraint stress. Body temperature increased during restraint in both groups (effect of time: $\left.p<0.001, F_{(3,32)}=97.507\right)$; however, the increase in $\mathrm{Tb}$ was significantly lower after intra-PAG microinjection of $1 \mu \mathrm{g}$, but not $10 \mu \mathrm{g}$, of CTAP (effect of treatment: $p=0.005, F_{(3,32)}=5.093$; no interaction effect of time and treatment: $p=0.793, F_{(3,32)}=0.753$; Fig. 3a). The HLI decreased during restraint and then increased shortly after (effect of time: $p<0.001, F_{(3,32)}=28.715$; Fig. 3b), but no difference among treatments was observed (no effect of treatment: $\left.p=0.670, F_{(3,32)}=0.523\right)$. Figure 4 depicts the thermal images of the rat tail before, during $(10 \mathrm{~min})$ and just after restraint stress in a representative animal injected with saline.

As $1 \mu \mathrm{g} / 100 \mathrm{~nL}$ of CTAP intra-PAG affected the increase in $\mathrm{Tb}$ during restraint, this concentration of CTAP was chosen for the experiments measuring the thermogenic effector
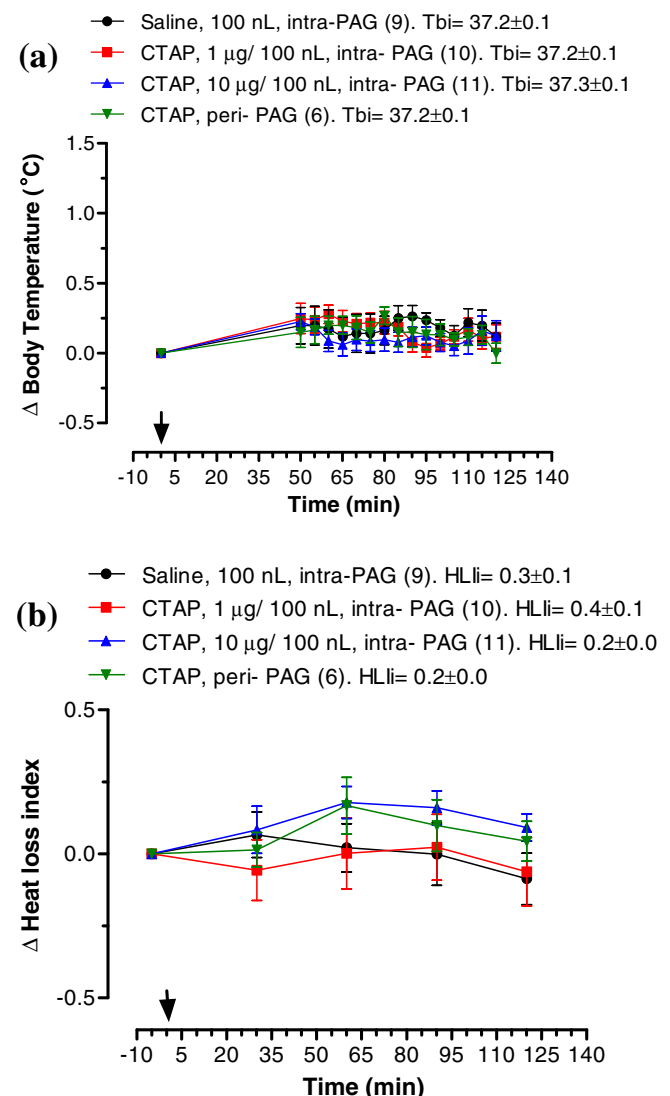

Fig. 2 Effect of microinjection of the mu opioid receptor antagonist CTAP ( 1 and $10 \mu \mathrm{g} / 100 \mathrm{~nL} /$ animal) or saline (vehicle; $100 \mathrm{~nL}$ ) in the periaqueductal gray matter $(P A G)$ on body temperature (a) and heat loss index (b) in animals not subjected to restraint. The arrow indicates the time of microinjection. The number of animals in each group is shown in parentheses. $\mathrm{Tbi}\left({ }^{\circ} \mathrm{C}\right)$ is the mean body temperature before any treatment, and HLIi is the mean heat loss index before any treatment

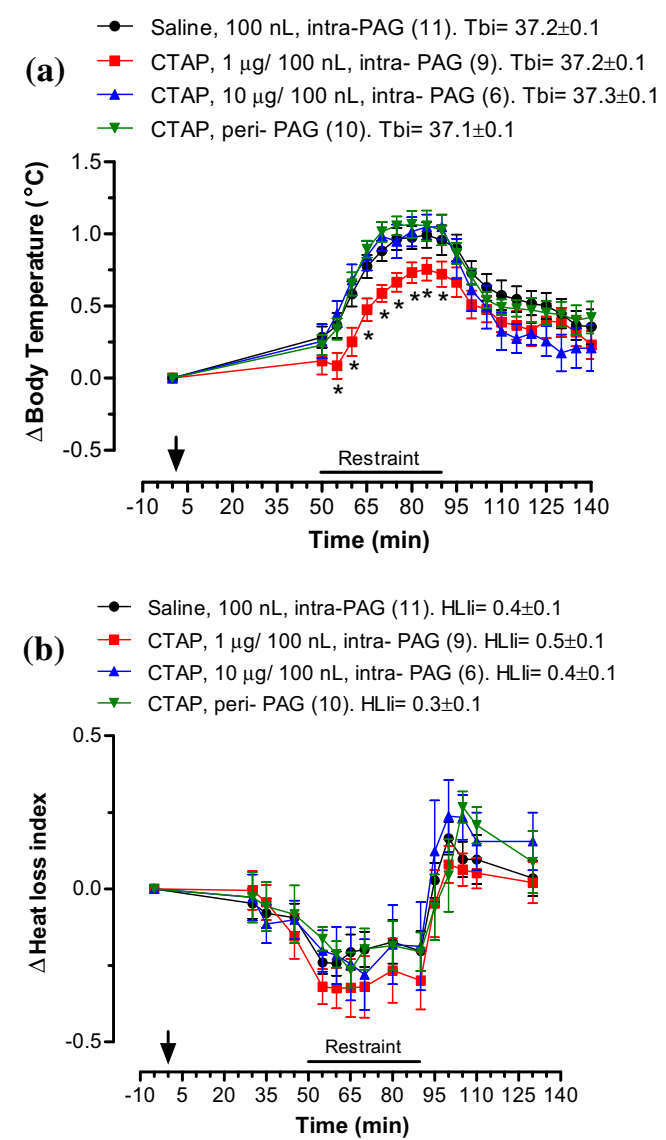

Fig. 3 Effect of microinjection of the mu opioid receptor antagonist CTAP ( 1 and $10 \mu \mathrm{g} / 100 \mathrm{~nL} /$ animal) or saline (vehicle; $100 \mathrm{~nL}$ ) in the periaqueductal gray matter $(P A G)$ on body temperature (a) and heat loss index (b) in animals subjected to restraint. The arrow indicates the time of microinjection. The number of animals in each group is shown in parentheses. Tbi $\left({ }^{\circ} \mathrm{C}\right)$ is the mean body temperature before any treatment, and HLIi is the mean heat loss index before any treatment. $* p<0.05$, significant difference from the saline group

during stress. Figure 5a shows that there was no difference in oxygen consumption between CTAP and saline groups in rats that were not subjected to restraint stress (no effect of time: $p=0.733, F_{(2,14)}=0.557$; no effect of treatment: $\left.p=0.659, F_{(2,14)}=0.429\right)$. During restraint, however, oxygen consumption increased in both groups (effect of time: $\left.p<0.001, F_{(2,18)}=26.708\right)$, but CTAP reduced this response (effect of treatment: $p=0.022, F_{(2,18)}=4.727$; no interaction effect of time and treatment: $p=0.972, F_{(2,18)}=0.125$; Fig. 5b).

\section{Effect of intra-PAG microinjection of the selective kappa opioid receptor antagonist, nor-BNI, on the Tb, HLI, and $\dot{\mathrm{V}} \mathrm{O}_{2}$ of restrained and unrestrained rats}

Figure 6 shows that treatment with nor-BNI induced no changes in $\mathrm{Tb}$ (no effect of time: $p=0.500, F_{(3,29)}=0.955$; no effect of treatment: $p=0.676, F_{(3,29)}=0.515$; Fig. $\left.6 \mathrm{a}\right)$ or HLI in non-stressed rats (no effect of time: $p=0.187$, 


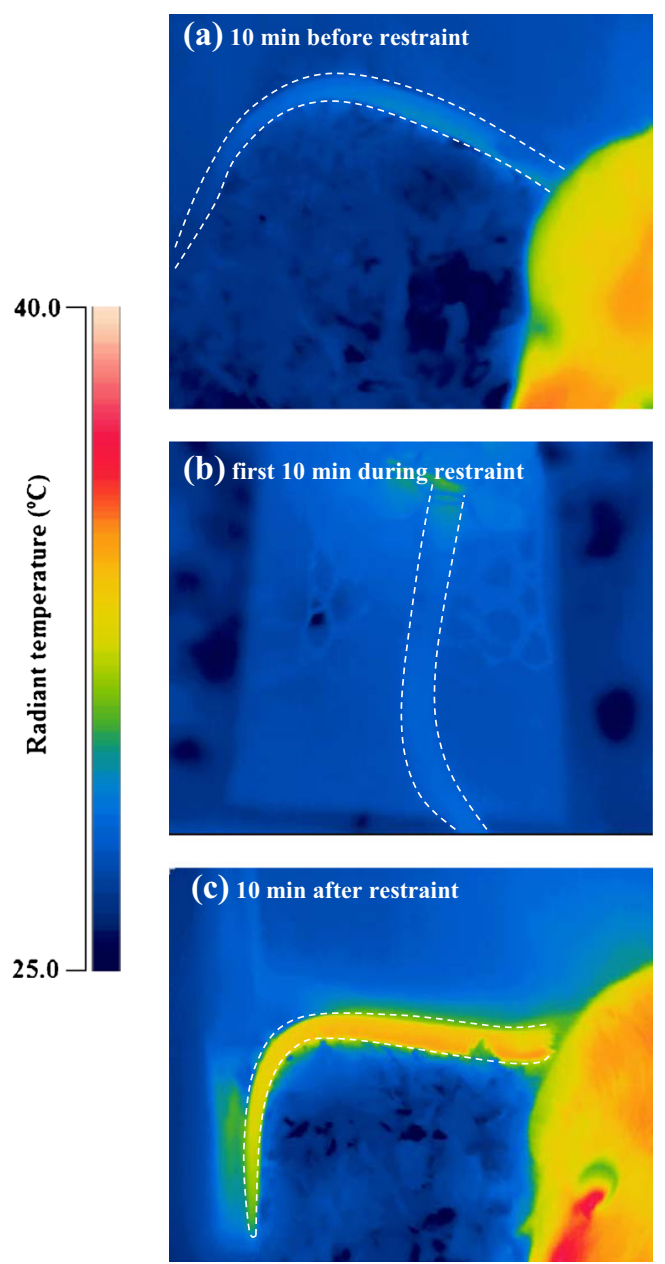

Fig. 4 Thermographic images of the tail of a representative rat in the control group (saline) $10 \mathrm{~min}$ before (a), during (b), and $10 \mathrm{~min}$ after (c) restraint

$F_{(3,29)}=1.644$; no effect of treatment: $p=0.333$, $F_{(3,29)}=1.194$; Fig. 6b). During restraint stress, Tb increased in both saline and nor-BNI groups (effect of time: $p<0.001$, $F_{(3,30)}=77.263$; Fig. 7 a); however, animals treated with the lower dose of nor-BNI intra-PAG presented a further increase in $\mathrm{Tb}$ (effect of treatment: $p=0.040, F_{(3,30)}=3.128$; no interaction effect of time and treatment: $p=0.808, F_{(3,30)}=0.739$; Fig. 7a). The HLI increased similarly in all groups after restraint (effect of time: $p<0.001, F_{(3,30)}=20.993$; no effect of treatment: $p=0.440, F_{(3,30)}=0.846$; Figs. 4 and $7 b$ ).

Figure 8a shows that there was no difference in oxygen consumption between nor-BNI and saline groups in rats that were not subjected to restraint stress (no effect of time: $p=0.071, F_{(2,17)}=2.122$; no effect of treatment: $p=0.803$, $\left.F_{(2,17)}=0.223\right)$. During restraint stress, however, oxygen consumption increased in both groups (effect of time: $p<0.001$, $\left.F_{(2,19)}=45.808\right)$, but nor-BNI intensified this response (effect of treatment: $p=0.037, F_{(2,19)}=3 ; 952$; no interaction effect of time and treatment: $p=0.267, F_{(2,19)}=1.357$; Fig. $\left.8 \mathrm{~b}\right)$.
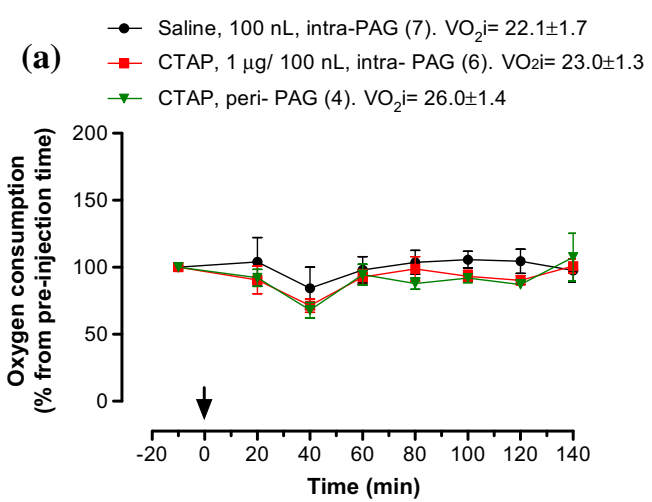

(b) $\rightarrow$ Saline, $100 \mathrm{~nL}$, intra-PAG (6). $\mathrm{VO}_{2} \mathrm{i}=24.8 \pm 2.4$
$\rightarrow$ CTAP, $1 \mu \mathrm{g} / 100 \mathrm{~nL}$, intra- PAG (7). VO $\mathrm{V}_{2} \mathrm{i}=24.8 \pm 2.7$

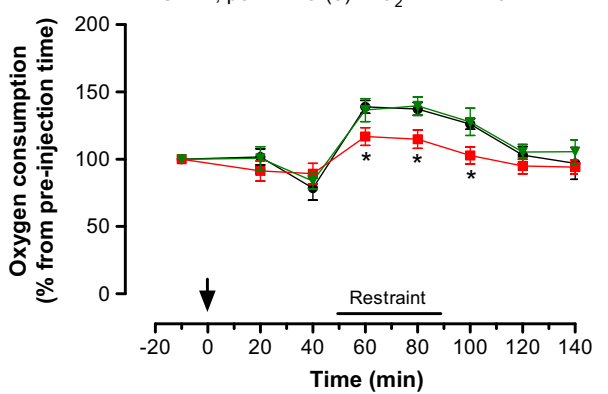

Fig. 5 Effect of microinjection of the mu opioid receptor antagonist CTAP $(1 \mu \mathrm{g} / 100 \mathrm{~nL} / \mathrm{animal})$ or saline (vehicle; $100 \mathrm{~nL})$ in the periaqueductal gray matter $(P A G)$ on oxygen consumption in animals not subjected (a) and subjected (b) to restraint. The arrow indicates the time of microinjection. The number of animals in each group is shown in parentheses. $\mathrm{VO}_{2} \mathrm{i}\left(\mathrm{mL} \mathrm{kg}{ }^{-1} \mathrm{~min}^{-1} \mathrm{STPD}\right)$ is the mean oxygen consumption before any treatment. $* p<0.05$, significant difference from the saline group

\section{Discussion}

The present results confirm our hypothesis that the mu and kappa opioid receptors, located in the PAG, modulate fever induced by restraint stress in rats, stimulating and inhibiting this response, respectively. They present this action, not by affecting heat conservation but by increasing $(\mathrm{mu})$ and decreasing (kappa) thermogenesis during restraint (Fig. 9). To our knowledge, this is the first demonstration of the thermoregulatory effectors involved in restraint stress, as well as their specific modulations in the brain.

There is enough evidence in the literature on the participation of mu and kappa receptors in stress responses [5] and in the regulation of $\mathrm{Tb}[2-4,8,9,17,18,22,34,35,38,39,77$, $81,91,98]$. Our previous data are consistent with the participation of opioid receptors in the preoptic area (POA) in anapyrexia (regulated decrease in $\mathrm{Tb}$, the opposite response of fever) induced by hypoxia; i.e., kappa opioid receptors are involved in the reduction of $\mathrm{Tb}$ during hypoxia and mu opioid receptors are important for the return of $\mathrm{Tb}$ to the state of posthypoxia normoxic euthermy [77]. Corroborating those data, 

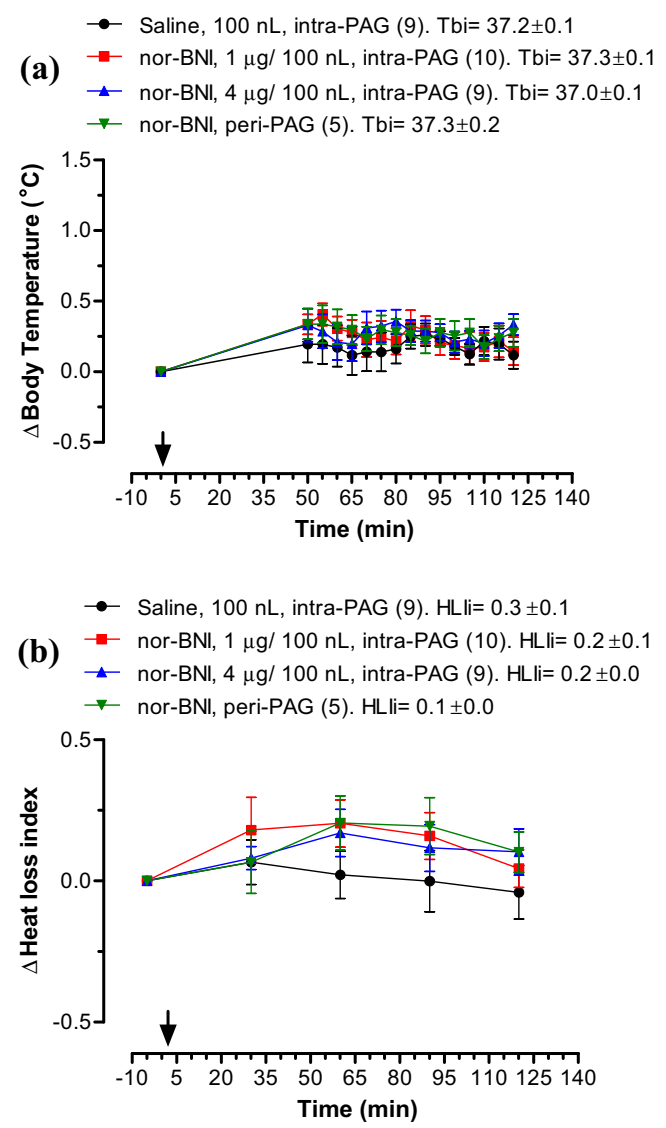

Fig. 6 Effect of microinjection of the kappa opioid receptor antagonist nor-BNI (1 and $4 \mu \mathrm{g} / 100 \mathrm{~nL} /$ animal) or saline (vehicle; $100 \mathrm{~nL}$ ) in the periaqueductal gray matter $(P A G)$ on body temperature (a) and heat loss index (b) in animals not subjected to restraint. The arrow indicates the time of microinjection. The number of animals in each group is shown in parentheses. Tbi $\left({ }^{\circ} \mathrm{C}\right)$ is the mean body temperature before any treatment, and HLIi is the mean heat loss index before any treatment

the microinjection of nor-BNI in the POA of squirrels causes an increase in Tb during hibernation [95], which is a condition also considered a regulated decrease in $\mathrm{Tb}$ due to metabolic depression [10]. Moreover, mu opioid receptors, especially in the hypothalamus, have been implicated in the increase in $\mathrm{Tb}$ during endotoxin-induced fever $[32,86]$.

The fever response is characterized by the activation of mechanisms for heat conservation (cutaneous vasoconstriction) and production (thermogenesis) $[6,15]$. In our study, during restraint, the HLI decreased (indicating peripheral vasoconstriction) in parallel with the increase in $\mathrm{Tb}$, and at the end of the restraint, the HLI increased (indicating peripheral vasodilation) in parallel with the return of $\mathrm{Tb}$ to euthermic values. The treatments with antagonists did not affect tail vasoconstriction/vasodilation during and post-restraint, indicating kappa and mu in the $\mathrm{dl} / \mathrm{dmPAG}$ are not involved in the modulation of this febrile thermoeffector. These results, however, do not exclude the possible modulation of heat conservation by these receptors in other regions of PAG, such as rostral PAG [94]. For mu receptors, their pyrogenic action in
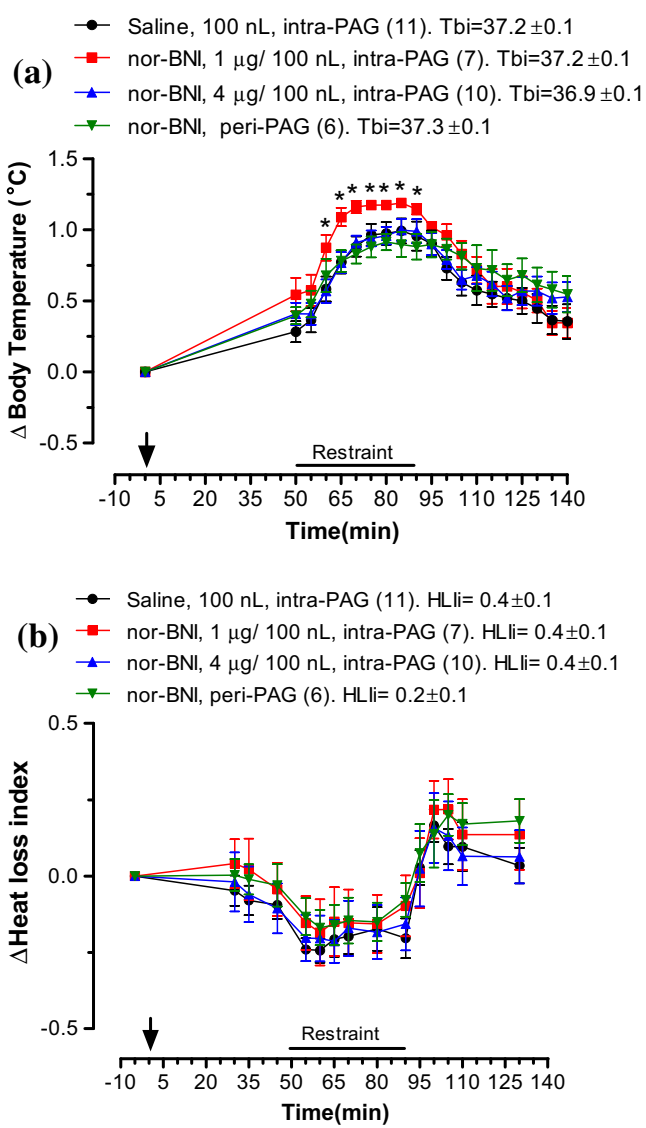

Fig. 7 Effect of microinjection of the kappa opioid receptor antagonist nor-BNI (1 and $4 \mu \mathrm{g} / 100 \mathrm{~nL} /$ animal) or saline (vehicle; $100 \mathrm{~nL}$ ) in the periaqueductal gray matter (PAG) on body temperature (a) and heat loss index (b) in animals subjected to restraint. The arrow indicates the time of microinjection. The number of animals in each group is shown in parentheses. $\mathrm{Tbi}\left({ }^{\circ} \mathrm{C}\right)$ is mean body temperature before any treatment and HLIi is mean heat loss index before any treatment. $* p<0.05$ significant difference from the saline group

$\mathrm{dl} / \mathrm{dmPAG}$ seems to be related to the activation of the thermogenic thermoeffector, because CTAP decreased oxygen consumption during restraint, while $\mathrm{Tb}$ also decreased. In contrast, for the kappa receptors, the inhibition of thermogenesis seems to be involved in their antipyretic action in the PAG, because nor-BNI increased oxygen consumption during restraint, while $\mathrm{Tb}$ increased.

The neural mechanism that links psychological stress to an acute or chronic elevation of $\mathrm{Tb}$ is still not fully understood, but the studies by Lkhagvasuren et al. [58] and Kataoka et al. [48] provide evidence that the increase in $\mathrm{Tb}$, at least that which is induced by social defeat stress, involves the participation of the $\mathrm{DMH}$, which receives inputs from preoptic neurons and sends outputs to the rostral medullary raphe (rMR). This neural pathway activates the sympathetic nervous system responsible for stimulating cutaneous vasoconstriction and thermogenesis of BAT $[58,64]$. According to the present study, opioid systems in the dorsal PAG may be part of this circuitry involved in thermoregulation during psychological 
(a) $\quad \rightarrow$ Saline, $100 \mathrm{~nL}$, intra-PAG $(7) . \mathrm{VO}_{2} \mathrm{i}=22.1 \pm 1.7$
$\quad \rightarrow$ nor-BNI, $1 \mu \mathrm{g} / 100 \mathrm{~nL}$, intra-PAG $(7) . \mathrm{VO}_{2} \mathrm{i}=22.6 \pm 1.6$
$\rightarrow$ nor-BNI, peri-PAG (6). $\mathrm{VO}_{2} \mathrm{i}=22.8 \pm 2.4$
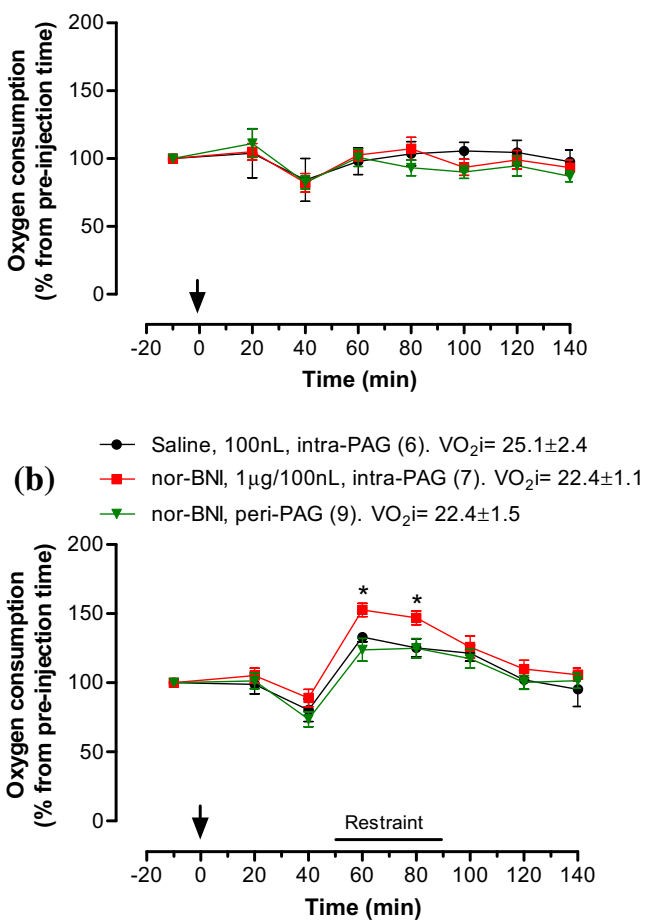

Fig. 8 Effect of microinjection of the kappa opioid receptor antagonist norBNI $(1 \mu \mathrm{g} / 100 \mathrm{~nL} /$ animal) or saline (vehicle; $100 \mathrm{~nL})$ in the periaqueductal gray matter $(P A G)$ on oxygen consumption in animals not subjected (a) and subjected (b) to restraint. The arrow indicates the time of microinjection. The number of animals in each group is shown in parentheses. $\mathrm{VO}_{2} \mathrm{i}$ $\left(\mathrm{mL} \mathrm{kg}{ }^{-1} \mathrm{~min}^{-1} \mathrm{STPD}\right)$ is the mean oxygen consumption before any treatment. ${ }^{*} p<0.05$, significant difference from the saline group

stress. There are excitatory connections between DMH and 1/ dlPAG $[25,26,94]$ which seem to be important for

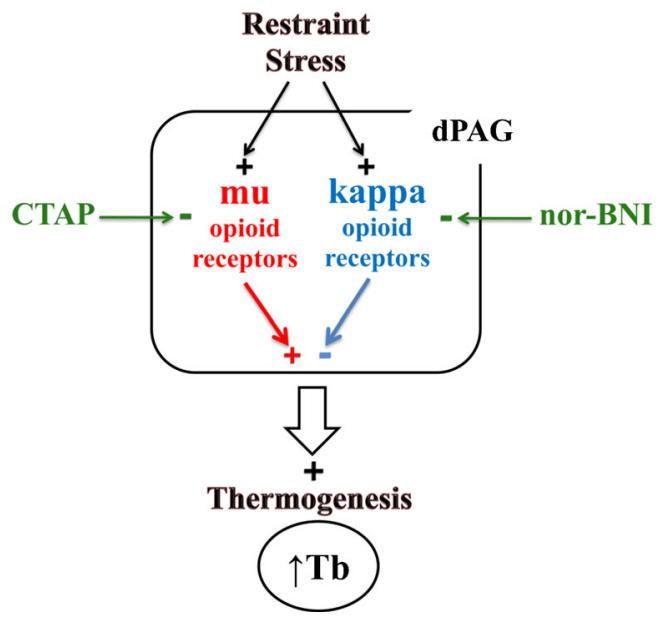

Fig. 9 Diagram showing that the thermogenesis activated during restraint stress is stimulated by mu opioid receptors and inhibited by kappa opioid receptors in the dorsal PAG $(d P A G)$. CTAP and nor-BNI antagonizes mu and kappa receptors, respectively. Plus sign stimulation; minus sign inhibition. See text for details thermogenic responses. In turn, the DMH can be activated by acute emotional stimulation and has functional connections with structures involved in fear and stress situations, such as the amygdala [55, 56, 76, 79]. There is also evidence for projections from the PAG to the raphe magnus [43], which has been implicated in analgesia [12] and the activation of non-shivering thermogenesis [48, 64].

Approximately $50 \%$ of the PAG neurons are GABAergic interneurons $[65,72]$. At least for the analgesic effect of opioids on the PAG, it has been demonstrated an inhibition of GABAergic synaptic transmission is controlled by a voltagedependent potassium conductance as the result of the activation of the mu receptors in the presynaptic terminals [88]. Thus, a suppression of GABA transmission in the PAG by the activation of mu receptors may be a mechanism involved in the activation of BAT thermogenesis mediated by the rMR. In contrast, a predominant suppression of excitatory synapses by a reduction of glutamate transmission in the PAG by kappa receptors may be a mechanism involved in the inhibition of rMR-mediated non-shivering thermogenesis. At least in the nucleus accumbens, the activation of kappa receptors inhibits the release of glutamate along with the entry of calcium [41, 42]. Another possible mechanism for kappa action in the PAG would be via interaction with nitric oxide (NO) neurotransmission, which inhibits neuronal discharge of the dIPAG [37, 61]. There is evidence of colocalization of kappa receptors and NO synthase (NOS) protein in neurons of PAG, which are suggested to be involved in the same intracellular network that controls morphine tolerance and dependence [40]. Moreover, $\mathrm{NO}$ is known to potentiate the presynaptic release of GABA in dlPAG, which in turn activates $\mathrm{GABA}_{\mathrm{B}}$ receptors in glutamatergic terminals reducing local release of glutamate [93]. Indeed, NO in dIPAG may play a role in inhibiting fever induced by restraint in rats, an issue that is currently under investigation in our laboratory.

Only the lower tested concentrations of the opioid receptor antagonists, CTAP and nor-BNI, had an effect on $\mathrm{Tb}$ in the present study. A similar pattern of responses was previously observed by us on $\mathrm{Tb}$ changes after hypoxia in rats injected with naltrindole (delta opioid receptor antagonist) in the POA [77] and on hyperventilation induced by hypoxia in rats injected with WAY100635 (5- $\mathrm{HT}_{1 \mathrm{~A}}$ receptor antagonist) in the POA [33]. The possible explanation for those effects is that high doses of antagonists may lead to their interaction with different targets. Chen et al. [24] suggested that there is a tonic balance between mu and kappa receptors and that with high doses of a pharmacological agent, it may act as an antagonist or agonist of other receptors. Moreover, Baker and Meert [9] have shown that opioid-induced hypothermia can be modulated by multiple receptors in the opioid system, which have the ability to interact with each other. Therefore, the largest concentrations (higher than $1 \mu \mathrm{g} / 100 \mathrm{~nL}$ ) of the antagonists used in our protocols may have been too high. In fact, the most 
effective dose of nor-BNI injected in the POA for inhibiting $\mathrm{Tb}$ reduction during hypoxia was $1 \mu \mathrm{g} / 100 \mathrm{~nL}$, with a minor effect of a concentration ten times lower [77].

In conclusion, our results are compatible with the idea that mu and kappa opioid receptors of the dorsal PAG play roles as pyrogenic and antipyretic molecules, respectively, during restraint stress-induced fever in rats by affecting the thermogenic, but not the heat conservation, thermoregulatory effector. The existence of those contrasting modulations by endogenous opioids in the PAG brings new insights for the understanding of interactive mechanisms between psychological stress and temperature regulation.

Acknowledgments This work was supported by the Fundação de Amparo à Pesquisa do Estado de São Paulo (FAPESP undergraduate fellowship 2013/02813-9 to C.C.S.; grant 2015/04849-6 to K.C.B.) and Coordenação de Aperfeiçoamento de Pessoal de Nível Superior (CAPES graduate fellowships to C.C.S. and V.M.). This study was part of the activities developed by C.C.S. for obtaining a master's degree at the Joint Graduate Program in Physiological Sciences (PIPGCF) from UFSCar/UNESP. We thank Euclides Roberto Secato and Damares Perecim Roviero for their technical assistance.

\section{Compliance with ethical standards}

Conflict of interest The authors declare that they have no competing interests.

Ethical standards All procedures performed in studies involving animals were in accordance with the ethical standards of the institution or practice at which the studies were conducted.

\section{References}

1. Abbruscato TJ, Thomas SA, Hruby VJ, Davis TP (1997) Bloodbrain barrier permeability and bioavailability of a highly potent and mu-selective opioid receptor antagonist, CTAP: comparison with morphine. J Pharmacol Exp Ther 280(1):402-409

2. Adler MW, Geller EB (1993) Physiological functions of opioids: temperature regulation. In: A Herz (ed) Handbook of experimental pharmacology: opioids II. Springer, Berlin, pp. 205-229

3. Adler MW, Hawk C, Geller EB (1983) Comparison of intraventricular morphine and opioid peptides on body temperature temperature of rats. In: Lomax P, Schönbaum E (eds) Environment drugs and thermoregulation. Karger, Basel, pp 90-93

4. Adler MW, Geller EB, Rosow CE, Cochin J (1988) The opioid system and temperature regulation. Annu Rev Pharmacol Toxicol 28:429-449. doi:10.1146/annurev.pa.28.040188.002241

5. Akil H, Watson SJ, Young E, Khachaturian H, Walker JM (1984) Endogenous opioids: biology and function. Annu Rev Neurosci 7: 223-255. doi:10.1146/annurev.ne.07.030184.001255

6. Almeida MC, Steiner AA, Coimbra NC, Branco LG (2004) Thermoeffector neuronal pathways in fever: a study in rats showing a new role of the locus coeruleus. J Physiol 558(Pt 1):283-294. doi: 10.1113/jphysiol.2004.066654

7. Almeida MC, Steiner AA, Branco LGS, Romanovsky AA (2006) Cold-seeking behavior as a thermoregulatory strategy in systemic inflammation. Eur J Neurosci 23(12):3359-3367. doi:10.1111/j. 1460-9568.2006.04854.x
8. Appelbaum BD, Holtzman SG (1986) Stress-induced changes in the analgesic and thermic effects of opioid peptides in the rat. Brain Res 377(2):330-336

9. Baker AK, Meert TF (2002) Functional effects of systemically administered agonists and antagonists of mu delta and kappa opioid receptor subtypes on body temperature in mice. J Pharmacol Exp Ther 302(3):1253-1264. doi:10.1124/jpet.102.037655

10. Barros RC, Zimmer ME, Branco LG, Milsom WK (2001) Hypoxic metabolic response of the golden-mantled ground squirrel. J Appl Physiol 91(2):603-612

11. Behbehani MM (1995) Functional caracteristics of the midbrain periaqueductal gray. Prog Neurobiol 46(6):575-605

12. Behbehani MM, Fields HL (1979) Evidence that an excitatory connection between the periaqueductal grey and nucleus raphe magnus mediates stimulation produced analgesia. Brain Res 170(1):85-93

13. Benamar K, Xin L, Geller EB, Adler MW (2000) Blockade of lipopolysaccharide-induced fever by a $\mu$-opioid receptor-selective antagonist in rats. Eur J Pharmacol 401(2):161-165

14. Benamar K, McMenamin M, Geller EB, Chung YG, Pintar JE, Adler MW (2005) Unresponsiveness of mu-opioid receptor knockout mice to lipopolysaccharide-induced fever. Br J Pharmacol 144(8):1029-1031. doi:10.1038/sj.bjp.0706145

15. Bícego KC, Barros RCH, Branco LGS (2007) Physiology of temperature regulation: comparative aspects. Comp Biochem Physiol A Mol Integr Physiol 147(3):616-639. doi:10.1016/j.cbpa.2006.06.032

16. Bishop D (2003) Warm up I: potential mechanisms and the effects of passive warm up on exercise performance. Sports Med 33(6): 439-454

17. Bodnar RJ, Klein GE (2005) Endogenous opiates and behaviour: 2004. Peptides 26(12):2629-2711. doi:10.1016/j.peptides.2005.06.010

18. Bradley EA, Geller EB, Piliero T, Adler MW (1991) Actions of $\mu$ selective opioid agonists and antagonists on body temperature in the rat. FASEB J5:A861

19. Broccardo M, Improta G (1992) Hypothermic effect of D-Aladeltorphin II a selective $\delta$ opioid receptor agonist. Neurosci Lett 139(2):209-212

20. Burkett JP, Spiegel LL, Inoue K, Az M, Young LJ (2011) Activation of $\mu$-opioid receptors in the dorsal striatum is necessary for adult social attachment in monogamous prairie voles. Neuropsychopharmacology 36(11):2200-2210. doi:10.1038/npp. 2011.117

21. Cabanac M, Gosselin F (1993) Emotional fever in the lizard Callopistesmaculatus (Teiidae). Anim Beh 46(1):200-202. doi: 10.1006/anbe.1993.1178

22. Cavicchini E, Candeletti S, Ferri S (1988) Effects of dynorphins on body temperature of rats. Pharmacol Res Commun 20(7):603-604

23. Chen XM, Nishi M, Nagashima K, Shibata M, Kanosue K (2002) The caudal periaqueductal gray participates in the activation of brown adipose tissue in rats. Neurosci Lett 331(1):17-20

24. Chen X, McClatchy DB, Geller EB, Tallarida RJ, Adler MW (2005) The dynamic relationship between mu and kappa opioid receptors in body temperature regulation. Life Sci 78(4):329-333. doi:10.1016/j.lfs.2005.04.084

25. Chen T, Hui R, Wang XL, Zhang T, Dong YX, Li YQ (2008) Origins of endomorphin-immunoreactive fibers and terminals in different columns of the periaqueductal gray in the rat. J Comp Neurol 509(1):72-87. doi:10.1002/cne.21728

26. De Menezes RC, Zaretsky DV, Fontes MA, Dimicco JA (2009) Cardiovascular and thermal responses evoked from the periaqueductal grey require neuronal activity in the hypothalamus. J Physiol 587(Pt6):1201-1215. doi:10.1113/jphysiol.2008.161463

27. De Paula D, Steiner A, Branco LGS (2000) The nitric oxide pathway is a important modulator of stress-induced fever in rats. Physiol Beh 70(5):505-511

28. Del-Ben CM, Graeff FG (2009) Panic disorder: is the PAG involved? Neural Plasticity 2009(2009):1-9 
29. Endoh T, Matsuura H, Tanaka C, Nagase H (1992) Norbinaltorphimine: a potent and selective kappa-opioid receptor antagonist with long-lasting activity in vivo. Arch Int Pharmacodyn Ther 316:30-42

30. Falcon-Lesses M, Proger SH (1930) Psychogenic fever. N Engl J Med 203:1034-1036. doi:10.1056/NEJM193011202032113

31. Finley JCW, Lindstrom P, Petrusz P (1981) Immunocytochemical localization of beta-endorphincontaining neurons in rat brain. Neuroendocrinology 33(1):28-42

32. Fraga D, Machado RR, Fernandes LC, Souza GE, Zampronio AR (2008) Endogenous opioids: role in prostaglandin-dependent and independent fever. Am J Physiol Regul Integr Comp Physiol 294(2):R411-R420. doi:10.1152/ajpregu.00465.2007

33. Gargaglioni LH, Bícego KC, Nucci TB, Branco LG (2006) Serotoninergic receptors in the anteroventral preoptic region modulate the hypoxic ventilatory response. Respir Physiol Neurobiol 153(1):1-13. doi:10.1016/j.resp.2005.09.003

34. Geller EB, Hawk C, Keinath SH, Tallarida RJ, Adler MW (1983) Subclasses of opioids based on body temperature change in rats: acute subcutaneous administration. J Pharmacol Exp Ther 225(2): 391-398

35. Geller EB, Rowan CH, Adler MW (1986) Body temperature effects of opioids in rats: intracerebroventricular administration. Pharmacol Biochem Behav 24(6):1761-1765

36. Gutstein HB, Mansour A, Watson SJ, Akil H, Fields HL (1998) Mu and kappa opioid receptors in periaqueductal gray and rostral ventromedial medulla. Neuroreport 9(8):1777-1781

37. Hall CW, Behbehani MM (1998) Synaptic effects of nitric oxide on enkephalinergic, GABAergic, and glutamatergic networks of the rat periaqueductal gray. Brain Res 805(1-2):69-87

38. Handler CM, Geller EB, Adler MW (1992) Effect of mu-, kappaand delta-selective opioid agonists on thermoregulation in the rat. Pharmacol Biochem Behav 43(4):1209-1216

39. Handler CM, Piliero TC, Geller EB, Adler MW (1994) Effect of ambient temperature on the ability of mu-, kappa- and deltaselective opioid agonists to modulate thermoregulatory mechanisms in rat. J Pharmacol Exp Ther 268(2):847-855

40. Herráez-Baranda LA, Carretero J, González-Sarmiento R, Laorden ML, Milanés MV, Rodríguez RE (2005) Evidence of involvement of the nNOS and the kappa-opioid receptor in the same intracellular network of the rat periaqueductal gray that controls morphine tolerance and dependence. Brain Res Mol Brain Res 137(1-2):166173. doi:10.1016/j.molbrainres.2005.03.003

41. Hjelmstad GO, Fields HL (2001) Kappa opioid receptor inhibition of glutamatergic transmission in the nucleus accumbens shell. J Neurophysiol 85(3):1153-1158

42. Hjelmstad GO, Fields HL (2003) Kappa opioid receptor activation in the nucleus accumbens inhibits glutamate and gaba release through different mechanisms. J Neurophysiol 89(5):2389-2395. doi:10.1152/jn.01115.2002

43. Hudson PM, Lumb BM (1996) Neurones in the midbrain periaqueductal grey send collateral projections to nucleus raphe magnus and the rostral ventrolateral medulla in the rat. Brain Res 733(1):138-141

44. Huey RB, Slatkin M (1976) Cost and benefits of lizard thermoregulation. Q Rev Biol 51(1):363-384

45. IUPS Thermal Commission (2001) Glossary of terms for thermal physiology. Jpn J Physiol 51:245-280

46. James IF, Goldstein A (1984) Site-directed alkylation of multiple opioid receptors. I. Binding selectivity. Mol Pharmacol 25(3):337-342

47. Jordan B, Devi LA (1998) Molecular mechanisms of opioid receptor signal transduction. Br J Anaesth 81(1):12-19

48. Kataoka N, Hioki H, Kaneko T, Nakamura K (2014) Psychological stress activates a dorsomedial hypothalamus-medullary raphe circuit driving brown adipose tissue thermogenesis and hyperthermia. Cell Metab 20(2):346-358. doi:10.1016/j.cmet.2014.05.018
49. Kishioka S, Kiguchi N, Kobayashi Y, Yamamoto C, Saika F, Wakida N, Ko MC, Woods JH (2013) Pharmacokinetic evidence for the long-lasting effect of nor-binaltorphimine, a potent kappa opioid receptor antagonist, in mice. Neurosci Lett 552:98-102. doi: 10.1016/j.neulet.2013.07.040

50. Kluger MJ (1991) Fever: role of pyrogens and cryogens. Physiol Rev 71(1):93-127

51. Kluger MJ, O'reilly B, Shope TR, Vander AJ (1987) Further evidence that stress hyperthermia is a fever. Physiol Behav 39(6):763-766

52. Kosterlitz HW, Corbett AD, Gillan MGC, McKnight AT, Paterson SJ, Robson LE (1985) Recent developments in the bioassay of opioids. Regul Pept Suppl 4:1-7

53. Koteja P (1996) Measuring energy metabolism with open-flow respirometric systems: which design to choose? Funct Ecol 10(5):675677. doi:10.2307/2390179

54. Law PY, Loh HH, Li CH (1979) Properties and location of betaendorphin receptor in rat brain. Proc Natl Acad Sci U S A76(11): 5455-5459

55. Ledoux JE (2000) Emotion circuits in the brain. Annu Rev Neurosci 23:155-184. doi:10.1146/annurev.neuro.23.1.155

56. Ledoux $\mathrm{J}$ (2003) The emotional brain fear and the amygdale. Cell Mol Neurobiol 23(4-5):727-738

57. Lemay LG, Vander AJ, Kluger MJ (1990) The effect of physiological stress on plasma interleukin-6 activity in rats. Physiol Behav 47(5):957-961

58. Lkhagvasuren B, Nakamura Y, Oka T, Sudo N, Nakamura K (2011) Social defeat stress induces hyperthermia through activation of thermoregulatory sympathetic premotor neurons in the medullary raphe region. Eur J Neurosci 34(9):1442-1452. doi:10.1111/j.1460-9568. 2011.07863.x

59. Lopes LT, Patrone LG, Coimbra NC, Bícego KC, Gargaglioni LH (2012) Periaqueductal gray matter modulates the hypercapnic ventilatory response. Pflugers Arch 464(2):155-166. doi:10.1007/ s00424-012-1119-6

60. Lopes LT, Biancardi V, Vieira EB, Leite-Panissi C, Bicego KC, Gargaglioni LH (2014) Participation of the dorsal periaqueductal grey matter in the hypoxic ventilatory response in unanaesthetized rats. Acta Physiol 211(3):528-537. doi:10.1111/apha.12254

61. Lovick TA, Key BJ (1996) Inhibitory effect of nitric oxide on neuronal activity in the periaqueductal grey matter of the rat. Exp Brain Res 108(3):382-388

62. Mansour A, Khachaturian H, Lewis ME, Akil H, Watson SJ (1987) Autoradiographic differentiation of mu delta and kappa opioid receptors in the rat forebrain and midbrain. J Neurosci 7(8):24452464

63. Minami M, Kuraishi Y, Yamaguchi T, Nakai S, Hirai Y, Satoh M (1991) Immobilization stress induces interleukin-1 $\beta$ mRNA in the rat hypothalamus. Neurosci Lett 123(2):254-256

64. Morrison SF, Madden CJ, Tupone D (2014) Central neural regulation of brown adipose tissue thermogenesis and energy expenditure. Cell Metab 19(5):741-756. doi:10.1016/j.cmet.2014.02.007

65. Mugnaini E, Oertel W (1985) An atlas of the distribution of GABAergic neurons and terminals in the rat CNS as revealed by GAD immunohistochemistry. In: Bjorklund A, Hokfel T (eds) Handbook of chemical neuroanatomy 4: GABA and neuropeptides in the CNS. Elsevier, Amsterdam

66. Nakamura K, Morrison SF (2007) Central efferent pathways mediating skin cooling evoked sympathetic thermogenesis in brown adipose tissue. Am J Physiol Regul Integr Comp Physiol 292(1): R127-R136. doi:10.1152/ajpregu.00427.2006

67. Oka T (2015) Psychogenic fever: how psychological stress affects body temperature in the clinical population. Temperature 2(3):368 378. doi:10.1080/23328940.2015.1056907

68. Oka T, Oka K, Hori T (2001) Mechanisms and mediators of psychological stress-induced rise in core temperature. Psychosom Med 63(3):476-486 
69. Paterson SJ, Robson LE, Kosterlitz HW (1983) Classification of opioid receptors. Br Med Bull 39:31-36

70. Paxinos G, Watson C (2005) The rat brain in stereotaxic coordinates. Elsevier Academic, San Diego

71. Rawls SM, Cowan A (2006) Modulation of delta opioid-evoked hypothermia in rats by WAY 100635 and fluoxetine. Neurosci Lett 398(3):319-324

72. Reichling DB (1991) GABAergic neuronal circuitry in the periaqueductal gray matter. In: Depaulis A, Brandler R (eds) The midbrain periaqueductal gray matter. Plenum, New York, pp 329-344

73. Romanovsky AA, Ivanov AI, Shimansky YP (2002) Molecular biology of thermoregulation: selected contribution: ambient temperature for experiments in rats: a new method for determining the zone of thermal neutrality. J Appl Physiol 92(6):2667-2679. doi:10.1152/japplphysiol.01173.2001

74. Salmi P, Kela J, Arvidsson U, Wahlestedt C (2003) Functional interactions between $\delta$ - and $\mu$-opioid receptors in rat thermoregulation. Eur J Pharmacol 458(1-2):101-106

75. Sanches DB, Carnio EC, Branco LGS (2003) Central nNOS is involved in restraint stress-induced fever: evidence for a cGMP pathway. Physiol Behav 80(1):139-145

76. Sanders SK, Shekhar A (1991) Blockade of GABAA receptors in the region of the anterior basolateral amygdala of rats elicits increases in heart rate and blood pressure. Brain Res 567(1):101-110

77. Scarpellini CS, Gargaglioni LH, Branco LGS, Bícego KC (2009) Role of preoptic opioid receptors in the body temperature reduction during hypoxia. Brain Res 25:66-74. doi:10.1016/j.brainres.2009.06.039

78. Singer R, Harker CT, Vander AJ, Kluger MJ (1986) Hyperthermia induced by open-field stress is blocked by salicylate. Physiol Behav 36(6):1179-1182

79. Soltis RP, Cook JC, Gregg AE, Stratton JM, Flickinger KA (1998) EAA receptors in the dorsomedial hypothalamic area mediate the cardiovascular response to activation of the amygdale. Am J Phys 275(2 Pt 2):R624-R631

80. Soriano RN, Branco LG (2010) Reduced stress fever is accompanied by increased glucocorticoids and reduced $\mathrm{PGE}_{2}$ in adult rats exposed to endotoxin as neonates. J Neuroimmunol 225(1-2):7781. doi:10.1016/j.jneuroim.2010.04.018

81. Spencer RL, Hruby VJ, Burks TF (1988) Body temperature response profiles for selective mu delta and kappa opioid agonists in restrained and unrestrained rats. J Pharmacol Exp Ther 246(1): 92-101

82. Steiner AA, Reste G, Branco LG (2003) Role of the brain hemeoxygenase-carbon monoxide pathway in stress fever in rats. Neurosci Lett 341(3):193-196

83. Tattersall G, Milsom WK (2003) Transient peripheral warming accompanies the hypoxic metabolic response in the golden-mantled ground squirrel. J Exp Biol 206(Pt 1):33-42
84. Tavares RF, Correa FM (2006) Role of the medial prefrontal cortexin cardiovascular responses to acute restraint in rats. Neuroscience 143(1): 231-240. doi:10.1016/j.neuroscience.2006.07.030

85. Terlouw EMC, Kent S, Cremona S, Dantzer R (1996) Effect of intracerebroventricular administration of vasopressin on stressinduced hyperthermiain rats. Physiol Behav 60(2):417-424

86. Tsai SM, Lin MT, Wang JJ, Huang WT (2003) Pyrogens enhanceendorphins release in hypothalamus and trigger fever that can be attenuated by buprenorphine. J Pharmacol Sci 93(2):155-162

87. Tseng LF, Wei ET, Loh HH, Li CH (1980) $\beta$-Endorphin: central sites of analgesia catalepsy and body temperature changes in rats. J Pharmacol Exp Ther 214(2):328-332

88. Vaughan CW, Ingram SL, Connor MA, Christie MJ (1997) How opioids inhibit GABA-mediated neurotransmission. Nature 390(6660):611-614. doi:10.1038/37610

89. Vizin RCL, Scarpellini CDS, Ishikawa DT, Correa GM, De Souza CO, Gargaglioni LH, Carrettiero DC, Bícego KC, Almeida MC (2015) TRPV4 activates autonomic and behavioural warmthdefence responses in Wistar rats. Acta Physiol 214(2):275-289. doi:10.1111/apha. 12477

90. Widdowson PS, Griffiths EC, Slater P (1983) Body temperature effects of opioids administered into the periaqueductal grey area of rat brain. Regul Pept 7(3):259-267

91. Wilson JR, Howard BA (1996) Effects of cold acclimation and central opioid processes on thermoregulation in rats. Pharmacol Biochem Behav 54(2):317-325

92. Xin L, Geller EB, Adler MW (1997) Body temperature and analgesic effects of selective mu and kappa opioid receptor agonists microdialyzed into rat brain. J Pharmacol Exp Ther 281(1):499-507

93. Xing J, Li DP, Li J (2008) Role of GABA receptors in nitric oxide inhibition of dorsolateral periaqueductal gray neurons. Neuropharmacology 54(4):734-744. doi:10.1016/j.neuropharm. 2007.12.008

94. Yoshida K, Konishi M, Nagashima K, Saper CB, Kanosue K (2005) Fos activation in hypothalamic neurons during cold or warm exposure: projections to periaqueductal gray matter. Neuroscience 1 33(4):1039-1046. doi:10.1016/j.neuroscience.2005.03.044

95. Yu LC, Cai YP (1993) Arousal following intra-preoptic area administration of naltrexone ICI 174864 or nor-BNI in hibernating ground squirrels. Brain Res 57(1):31-35

96. Zhang YH, Hosono T, Yanase-Fujiwara M, Chen XM, Kanosue K (1997a) Effect of midbrain stimulations on thermoregulatory vasomotor responses in rats. J Physiol 503(Pt 1):177-186

97. Zhang YH, Yamada K, Hosono T, Chen XM, Shiosaka S, Kanosue K (1997b) Efferent neuronal organization of thermoregulatory vasomotor control. Ann N Y Acad Sci 813:117-122

98. Zhang W, Hayward LF, Davenport PW (2007) Respiratory responses elicited by rostral versus caudal dorsal periaqueductal gray stimulation in rats. Auton Neurosci 134:45-54 